\title{
The Local Elections in Indonesia: Polemic, Conflict and Consensus of Transition to Local Democracy
}

\author{
Saiful Ahmad \\ Department of Political Science Muhammadiyah University of North Maluku, KH. Ahmad Dahlan Street No. 100 Ternate City, Indonesia

\begin{abstract}
This paper is the result of studies on the implementation of the local elections in Indonesia, especially in North Maluku province with a variety of conditions that occur, with the aim to provide solutions to the implementation of the local elections were in line with expectations towards a democratic state. To prevent communal conflict does not reoccur, program approach and professional services, the bureaucracy is possible to be developed, but need the support and participation of all stakeholders (Government, Parliament and the public). Therefore, there needs to be an integration of conflict prevention into policies, strategies, methods and approach to program development.
\end{abstract}

Keywords: Polemic, Conflict, Consensus of Transition, Local elections, Local democracy.

\section{Introduction}

Indonesia is one of the countries of Southeast Asia region, which has a very complicated political history, just recall the history stretches back to politics in this archipelago, Indonesia is a nation that is in the treasury barely recognized the concept of culture and the democratic system as it is now. The concept of democracy as we know it is like an egg tip of the spear, or likened graft goods imported from outside, namely from European and American countries. Noted Dutch colonial government that was most responsible, one of which is through education. Through Etishe Politiek at the beginning of the 20th century. Then from there began the rise of national consciousness in the Youth Oath Creed coined in 1928 by the youth of the various collections and entities in this archipelago.

The series of events from 1928 to 1945 as well as other events that have passed during this independence is also a series of dynamic process of democracy itself. As a nation we have been through turbeulensi of the democratic efforts. History also records since the beginning of independence in 1945 until 1959 was a time when we are trying to implement a Western-style democracy the government is really serious, because we want to prove to the world that Indonesia is an independent nation which is able to uphold democracy, as well as with the belief that this is the best political system to be applied in the realm of independent Indonesia at that time.

Thereafter, the period the issuance of Presidential Decree 1959 to 1999 or better known by the time of the Reformation, we also experienced the turbulence of efforts to implement the systems and practices of democracy that, then what is obtained, the process of involution, which is where we turn recede backwards to to the past long history of politics in this country, because we find it failed experiment with a Western democratic system that is obviously not suitable for us and not a portion of our culture.

Back to the old cultural values inherited by the heirs of this nation has been used as a new adage. The democratic system is known that only the structural frame and leather-skin deep, while the content and the substance are a political system that is intrinsically contradictory primordial and even contrary to the system and the principles of Western democracy itself. While the term "democracy" with all sorts of jargon that accompanies it is entirely modern, which do in fact is primordial political culture preservation efforts with the new packaging.

Confusion is a synthetic of a primordial political system of our ancestral culture with the system and the democratic principles that come from the West, so be the result as we see from the labels we give to Indonesia's democracy. In the Sukarno era name "guided democracy," and in the Suharto era name "Pancasila democracy". Both the democratic system, it's practically the same, namely the neo-feudalism etatik oriented, centralized, autocratic and totalitarian, in addition nepotik and despotic, by putting people back as subjects, not as a free person. Sovereignty does not lie in the hands of the people, but on the rulers of the State which governs authoritarian and dictatorial. As known to the democratic process of a nation is a complicated process, a comprehensive and often filled with political tension. This process generally deals with the forces of authoritarian regimes and the systematic repression. So Huntington (1995) said, the process of political change from authoritarianism to democracy has been overshadowed by a military coup (Tanuredjo, 2003).

For example, in the Suharto era, for the purposes of political stability, a prerequisite for development, the military is used as the spearhead of power, while for economic development consciously and systematically utilize the expertise and ingenuity groups of Chinese descent to drive the national economy, with curtain shield SARA to secure their activities. "A hundred years were given the opportunity to the people to develop the economy of the nation's tattered at the beginning of the New Order government as inherited Sukarno will not be overtaken," the pretext of a team of economic advisers of the group "Berkeley Mafia" that help define and design the pattern of the New Order economy. For that we need to utilize the expertise and ingenuity of the "Sedulur Turwo" (Chinese merchants) to rescue the Indonesian economy from 


\section{International Journal of Science and Research (IJSR) \\ ISSN (Online): 2319-7064}

Index Copernicus Value (2013): 6.14 | Impact Factor (2015): 6.391

the brink of destruction. Through limbo ersatz capitalism, they controlled and develop over time, the miracle happened. Within 5 five year plan's per capita income rose from 60 dollars to up to 1500 dollars, which represented a 25 -fold within 30 years. But the price to pay is that the economic and trade business anniversary Indonesia really is held almost entirely in the hands of the financiers and merchants of China, the same or even excess of their tenure description in other seacoast Nan Yang in Southeast Asia. The practice of corruption, collusion and nepotism $(\mathrm{KKN})$ while that too rampant and uncontrolled entrenched. Cooperation between the authorities and non-native entrepreneurs is that their economies, Indonesia during the New Order period. Ravines inequality and economic disparity and social-cultural increasingly gaping between the ruling elites and entrepreneurs with the most people. And the culmination of all this is that eventually led us to the era of reform to the fall of the Suharto era and changed by Habibie era.

\section{Literature Review}

\section{Democracy and Decentralization}

At the end of the length of a trip for 40 years (1959-1999) that we realized our mistake, to pass all the risks and consequences thereof, and we declare ourselves want to return to real democracy. The pendulum is now moving from what was to be neofeodal of the culture of our ancestors, to democracy more universal and egalitarian, with reemphasized to the rule of law and equality before the law and uphold human rights. In the middle of the wind revolution is the emergence of a desire to give autonomy to the regions that had been used as a cash cow by Jakarta (center).

History autonomy in these areas has actually long run, as they realized that democracy would not work without autonomy. Efforts to give autonomy to these regions in terms of the legislation of the Republic of old age itself. Legislation that was first issued after the proclamation of independence was Law No. 22 In 1948, Law No. 22 and 25 in 1999 and now Law No. 32 in 2004. Thus the Law 32 of 2004 which became the focus of attention and concern, we have now is the autonomy law which is the 9th for over half a century we are independent.

But the reality is, as we have seen yourself so far. Under Law no. 22 and 25 in 1999 instead of the autonomy and independence care of themselves obtained by the regions, but quite the opposite. Regional curbed and controlled from the center so that the local loss of independence and freedom. In fact, as said, the area became a cash cow for the benefit of the ruling party at the center and the center. On the other hand the Law no. 32 in 2004, re-legitimize local authorities into a small king in the area, and even make their own country or region as a state in the state. Even further than that, people created and mapped in the forms of mutually hostile groups as a result of local elections directly.

For example, North Maluku, as the autonomous regions, still holds a number of potential conflicts. The potential for conflict is everywhere, including in the political development. As is understandable in some quarters that the political factor is not everything, but through politics everything can change. One of them is the problem of democracy, arguing democracy, people can do (well-relative) otherwise without democracy could be labeled an anarchist. Among them is the process of local elections.

We should all remember very well that the concept and the democratic system did not automatically destroy the system and our culture. Robert A. Dahl (2001), for example, provides for the criteria and the signs for the democratic process. He gave the standard, there are at least five standard to say democracy, democracy provides opportunities for: 1). Effective participation, 2). Equations in the voting, 3). Getting a clear understanding, 4). Carry out final control of the agenda, and 5). The inclusion of adults for all or at least most of the adults who are permanent residents should have the right to full citizenship shown by the four previous criteria.

Although the Law on Regional Autonomy has experienced a change of Act No. 22 of 1999 to Act No. 32 of 2004. The occurrence of these positive legal changes has also impacted on the local democratic process. The existence of the Regional Autonomy Law No. 32 of 2004 on local government seems still far from realization of democracy that the public wants. Crisis after the local elections in some provinces (10 years) recently occurred as, in the province of Papua, Lampung, several districts in East Java, Depok City even in South Halmahera and West Halmahera 2005, a contributor to wrack face of democracy in Indonesia, although their impact is local but national. Among the issues which are not yet the fall of the Presidential Decree, the allegations of money politics to the Regional Head and Deputy Head of elected and even inflate Sound for a particular candidate. Basically, the constitution is designed properly will help the survival of democratic institutions, otherwise the constitution that is not designed well, which will also contribute to stagnant political institutions that reflect democracy.

\section{Democracy and Democratization}

The occurrence of the wide gap between the will of the state with the awareness of people (collective conscience). The success of the pioneers of independence to create awareness of new nationalism (nation building), not followed by success in the development of the state (state building) - in order to protect the entire Indonesian nation and the entire homeland of Indonesia, promote the general welfare, educating the nation, and participate in implementing order world based on lasting peace and social justice (paragraph IV of the Constitution 45).

Weak protection of the state against its people seen from the lack of attention and accountability in both the legislature (as the people's representative bodies) and the executive (as an institution servant of the people). The presence of postcolonial legislature more often presents itself as "Volksraad" in the colonial era, deprived of public aspirations and to act more as a political broker for the benefit of himself. Instead the presence of the executive branch, is presenting himself as a wild tiger ready to devour anyone who would be a good meal. Thus hopes to promote the general welfare, the nation 


\section{International Journal of Science and Research (IJSR) \\ ISSN (Online): 2319-7064}

Index Copernicus Value (2013): 6.14 | Impact Factor (2015): 6.391

is just a fantasy of the poor and marginalized, and to be otherwise advance the welfare and educate personal, family and cronyism, and to society appears only empty promises.

The passing of the new order exudes new expectations regarding the strengthening of civil rights, the economy, politics and culture of the people. Trustworthy representative democracy as a way to bring politics into the mass base of the grass roots. Since the reforms initiated in 1988, various changes in the level of democratic procedures have occurred. Government no longer appointed, but elected, elections relatively fair and repeatable, freedom of expression is guaranteed, information access extends (although there is no guarantee law), decentralization and autonomy enforced, presidential elections and the direct election starts.

But the minds of most people who have long suffered oppression, injustice and poverty, democracy symbolizes more than just a change of political institutions and the replacement of repressive authoritarian leaders. Democracy is expected to present the opportunities and resources for the improvement of quality of life and social life more just and humane (Shin, 1999). Therefore, the consolidation of democracy must ensure the realization of the essence of democracy: empowering the people (popular empowerment) and the liability of systemic (systemic responsiveness).

In fact, the ideals of empowerment of the people and public accountability is still far from expectations. Instituted legislation, for example, the regular expression of the people's representatives will prioritize power ambitions rather than to account for public mandate constituencies. Concern to improve the welfare of board members often seemed more passionate than fight tooth and nail for the improvement of people's welfare. Meanwhile, good and clean governance which is expected to emerge as the output of the democratic process has not become a reality. The level of corruption is likely to increase in the phase of transition to democracy. Under the democratic system has spread the power centers (the new kings area). As a result, there are more veto players (decision makers) than under the authoritarian regime, which gave way to the expansion of new centers of bribery.

When the legal system is still fragile and social disorganization occurs almost all lines, the necessary political actors as powerful as compensation. Ability asceticism and willingness to make a radical departure of politics as "the art of the possible" which connotes political horse-trading, towards politics as "the art of impossibility" that promises big changes (Latif, 2006), is the key to improvements in the quality of the driving legislative and executive.

\section{Methodology}

The study of this paper is the result of literature review from various sources, both the results of previous research, regulations and legislation, and interviews with some relevant sources. The study results are then analyzed qualitatively based studies related theory.

\section{Discussion}

\section{Political Dilemma of Election and Political Lessons}

After the collapse of the New Order regime, precisely after the 1945 amendment declared valid, the election of President / Vice President, governor / deputy governor, mayor / deputy mayor and regent / deputy regent no longer held by the government. Election officials, both national and local politics, organized by an independent commission, permanent and nationwide, the General Election Commission (KPU). Election of the president / vice president organized by the Commission, which is national, while the election of the governor / deputy governor, mayor / deputy mayor and regent / deputy regent organized by the Provincial Election Commission and the Election Commission of Regency / City. Previously, elections are held by the General Elections Institute (LPU) formed by the government and are under the control of the Ministry of the Interior. Selection of governor / vice governor hosted by DPRD Level I and designated by the Minister of the Interior on behalf of the President. While the selection of mayor / deputy mayor and regent / deputy regent organized by the Municipal Council / DPRD Level II and determined by the Governor on behalf of the Minister of Home Affairs.

Habits of the elections held by the LPU to elect members of the DPR / DPRD and the election of the President / Vice President of the People's Consultative Assembly (MPR) including custom election for governor / vice governor hosted by the Provincial Parliament (DPRD I) and the election of the mayor / deputy mayor and regent / deputy regent organized by parliament municipality (DPRD II). Concurrent stopped after the 1945 Article 22E Paragraph (5) the amendment / change III on 9 November 2001 stipulates that elections be held by an electoral commission which is national, permanent and independent. Pursuant to Article 22E Paragraph (5) of the 1945 Constitution, the Commission 2001-2007 period in 2004 for the first time in the history of Indonesia successfully implement direct elections to choose the President / Vice President.

After the Commission successfully implementing direct election of the President / Vice President, Election Commission of Provincial and district commissioner / City in June 2005 has also carried out direct elections of regional heads (elections) each to choose a governor / deputy governor at the provincial level, the mayor / deputy mayor in the city level, and regent / vice regent at the district level. The success of the Commission in 2001-2007 period direct general election to elect the President / Vice Presidentincluding direct elections of governors / vice governor, mayor / vice mayor and regent / vice regent, can be seen as the hallmark of Indonesian democracy after the fall of the New Order regime and or after the amendment of the 1945 Constitution.

But behind the success of the Commission held direct elections in 2004 and the success of the Provincial Election Commission and the Election Commission District / City conducting elections, some people remain anxious and dubious process of democratization in local politics after 


\section{International Journal of Science and Research (IJSR) \\ ISSN (Online): 2319-7064}

Index Copernicus Value (2013): 6.14 | Impact Factor (2015): 6.391

seeing the political conflicts that arise in the various elections. Anxiety comes as several election cases, such as the North Maluku elections in 2007 led to political division in society based primordial. Similarly, any doubts about the elections because they do not see any correlation between political officials generated by the elections and the completion of the local political problem fundamentally. Corruption, collusion and nepotism (KKN), which remains rampant, the cost of elections, which were not comparable with that obtained by the public welfare, as well as the division of society along primordial such as ethnic and religious conflicts are often the reason put forward by opponents of the elections. Deems the elections failed not only because it is not able to produce local leaders to prosper the people in the area, but also because of social integration is threatened as a result of the political division in society caused by political competition in elections.

Politics is the government, including those who implicitly and explicitly rejected the elections and or does not recognize the elections as an electoral regime with arguments efficiency and effectiveness of local governments, as well as social and political disintegration. It can be seen from the attitude of double standards, of government in the form of a role as a regulator and organizer in the elections as stipulated in the Act No. 32 of 2004 on Regional Government and the technically stipulated in Government Regulation (PP) No. 6 of 2005 on the Election, Ratification, Appointment and Dismissal of Regional Head and Deputy Regional Head. On the one hand, the government does not recognize the elections as an electoral regime, -like policies that make up the Department of Home Affairs 'Des elections' were involved as regulators and organizers, like a shadow of the Election Commission, but on the other hand also acknowledge the Provincial Election Commission and the Election Commission of Regency / City as the organizer of the elections. It was seen from the Court's decision in a lawsuit that the government won a judicial review against the PP No. 6 Years 2005 by a number of non-governmental organizations (NGOs) and Provincial and District / Municipal (Election Commission) (S. Haris, 2005).

Nevertheless, in spite of the controversy that surrounded him, the elections as an instrument of political democratization of local normative selected with the hope to become a means of participation in society in the recruitment of local politics, especially the recruitment of head / deputy head of the region, so as to create harmonious relations between the elite and the masses and relationship central regions. The election was considered as a way out not only by officials of the Central Government in the area during the New Order has failed in encouraging the democratization of local politics, especially the political participation of the people in the recruitment of local politics, but also failed in implementing the substance of autonomy, namely the welfare of the people in the area.

The organization of the elections by the Election Commission and the Election Commission, Provincial, District / City has to absorb the political aspirations of the local communities widest (extension of the right to vote) for the recruitment of local political leadership and the political policy: the creation of a local, such as the Regional Regulation (Perda). Elections are born of the spirit of the reform is expected to bring up the local political elites to manage decentralization and local governance with both in the sense of freedom from corruption, participatory, transparent, accountable, credible and capable.

But the reality of the matter is not entirely as expected. Conflict, political elite protracted due to dissatisfaction with the candidate pairs governor / deputy governor who lost in the elections, for example, has also led to and prolong political conflict that is based on primordial ties, such as ethnic conflict.

The most interesting case in the political drama in recent local elections that were sampled are elections and Deputy Regional Head of Depok City, West Java. After the election results known, Depok Election Commission on July 6, 2005 set a couple Nurmahmudi Ismail and Yuyun Wirasaputra as a candidate elected. That is essentially the Nurmahmudi victory is a victory for all citizens of Depok, including the four other candidate pairs. This is a victory of democracy (comments from analysts), because every voice of the people is worth, calculated and taken into account. Because the essence of democracy is respect for the people's voice in public decision making process, including choosing a leader.

The local elections Depok City eventually became a national issue and extensive public attention (Depok as cities buffer Jakarta, capital of Indonesia), when one of the candidates who do not accept the results and filed a lawsuit in the High Court of West Java. Unfortunately, common sense and conscience do not work optimally in the resolution of election disputes Depok in West Java High Court. The panel of judges has taken a controversial decision and contrary to common sense, the public conscience, and social facts field data. The results of the elections were democratic eventually overturned by the High Court of West Java and the judge then set a new winner. In terms of the evidence submitted to the Court the claimant was not based on facts field data, but rather on assumptions that are not valid (Sumarno, 2006).

Admittedly, the process of the lawsuit to high court of West Java Province is a dynamic political and democratic learning process is quite constructive. Recourse to the law in election disputes is provided for in the rules of law. This is the only respectable, responsible and civilized, to solve problems, not by violence, vigilantism, or in ways other anarchist counterproductive for the future of democracy. Because of this State, of Indonesia, is a state of law for the sake of legal certainty, it should work is common sense, conscience, and the fact the data field for the sake of democracy.

In this case, we do not need to dredge up old wounds elections in some districts (South Halmahera, West Halmahera) in North Maluku in 2005, recorded an anarchist, but what is needed is taking a valuable lesson that similar cases do not happen again and will not be repeated back in the country's Moloku Kie Raha. We should be more mature, more mature and even more to understand the values and ethics of democracy, because democracy can subvert boarding treasure and human life.

\section{Volume 5 Issue 5, May 2016}




\section{International Journal of Science and Research (IJSR) \\ ISSN (Online): 2319-7064}

Index Copernicus Value (2013): 6.14 | Impact Factor (2015): 6.391

\section{Mirror on North Maluku Election 2007}

In late 2005, an institution funded candidate, Abdul Gafur Centre (AGC), when launching inaugural speech Abdul Gafur (AG) has made the inconvenience to participants who attend the event, there arose a polemic like and dislike. It should be a momentum anything done by the children of this nation is a process of political education and community empowerment is interpreted as a process, not the beginning of the process of creating conflict. The earliest case of political celebration predicted injure the local democratic process, if not anticipated we all -according Arstotelespolitical creatures.

Just to list the candidates who will appear coloring Exchange 2007 elections soon, and touted ranging social investing. The called of Abdul Gafur (AG) with its AGC, Thaib Armayin (TA) with mr. reconciliation, Ahmad Hatary (AH) with the world football quiz, Yamin Tawari (YT) with its harsh criticism, Majid Abdullah (MA) with mr. peace, nor Mudafar Syah (MS) and even Abdul Gani Kasuba (AGK) with its social teaching. When analyzed, these figures can be divided into two categories, namely anyone has a political vehicle, and there is nothing but matter even capitalize social investment. Interestingly, among the characters are mostly having a trace recording virtually unknown by the people of North Maluku, potential and even have a political conflict.

In the recruitment of candidates, for example, also appeared four issues, namely (1) the bearer party's internal conflicts; (2) pairs of candidates from the age of twilight; (3) continuation of the previous conflict; (4) the emergence of ethnic sentiments. Thaib Armayin backed by a coalition party of PKS, PD, PKB, PBR, PBB and PKPB, time consumed due to internal party conflict. Similarly, Abdul Gafur-backed coalition of Golkar, PAN and PDK also has an internal party conflict. An internal party conflict took place in PD and PDIP. In the body of the Golkar Party also emerged internal conflict, the group that was under the command regional coordinator of Maluku province and North Maluku province led by M. Yamin Tawari and a group led by the chairman of the council of North Maluku is Mr. Hasan Doa, which finally Hasan Doa dismissed because it is considered not to follow DPP instructions.

After Sultan Ternate Mudaffar Sjah and Yamin Tawari failed to enter the stock candidates for governor / deputy governor, four candidates for Governor of North Maluku in the elections of 2007 that had escaped, namely: Thaib Armaiyn, Abdul Gafur, Antony Charles Sunaryo and Irvan Edison add to the long political issue. The emergence of the four candidates it is not just mapped the primordial basis of religion and ethnicity, but also all from the political elite of the older generation aged "aging" by the age of 55 years. The fourth candidate came under the spotlight as judged by a rival political elite have turned off the circulation process the elite in North Maluku. Occurrences Thaib Armaiyn, Abdul Gafur, Antony Charles Sunaryo and Irvan Edison has closed the doors for the next generation, such as M. Yamin Tawari to appear in local politics as a new local political leaders.

\section{Conclusion}

Built upon the assumption that the mere reminder of what is written by Markoff (1996) about the governor election violence Rodhe Island, England in 1814, IE There are two Governors, one of which have been selected based on the voting rights (franchise) and is a Governor formation of rebel groups. Both claim to be "free government" against tyranny and each accusing one another as Governor illegal. We certainly are aware and know exactly what is described Markoff undesirable happens to the Governor / Deputy Governor in 2007, and the Election of Regent / Deputy Regent and or Election of Mayor / Deputy Mayor in 2010, but it should be remembered wasn't This area has a history of election of Governor first almost similar to Queen Elizabeth's country. Things that remind us to prevent communal conflict does not reoccur, program approach and professional services, the bureaucracy is possible to be developed, but need the support and participation of all stakeholders (Government, Parliament and the public). Therefore, there needs to be an integration of conflict prevention into policies, strategies, methods and approach to program development.

\section{References}

[1] Anonymous, 2000, Assessment of Democracy in Indonesia, International IDEA, Stockhol Sweden.

[2] Anomimus, 2000, issue of Democracy and Autonomy, Side Socio-Cultural, Presented at the Round Table Discussion between experts, organized by the Consortium Indonesia for Empowerment of Regions (gait), Saturday, April 8, 2000, at Hotel Boulevard Park Plaza Slipi Jakarta.

[3] Dahl, Robert A., 2001.Perihal Democracy, Exploring Theory and Practice of Democracy in Brief, (trans. A. Rahman Zainuddin), Yayasan Obor Indonesia, Jakarta

[4] Haris, Syamsuddin, 2005, the Direct Election and the Future of Regional Autonomy, the Politika Journal Vol. May 1, 2005.

[5] Saefullah Fatah, EEP, 1999, Building Agenda Opposition Political Change the Future, Rosdakarya, Jakarta.

[6] Primary, Rama, 2006, Yang Young Yang Berparlemen, A Public Accounts, Earth Literacy, Jakarta.

[7] Sumarno 2006, Depok Election Political Drama, Badrul Kamal Sues Nurmahmudi Answering, Harakatuna, Jakarta.

[8] Tanuredjo, Budiman, 2003, the Military and Settlement of Human Rights Violations of the Soeharto era, (Graduate Thesis Politics, Social UI), Jakarta. 